\title{
Tropical Pacific Forcing of North American Medieval Megadroughts: Testing the Concept with an Atmosphere Model Forced by Coral-Reconstructed SSTs*
}

\author{
RichaRd SEAGER \\ Lamont-Doherty Earth Observatory of Columbia University, Palisades, New York \\ ROBERT BURGMAN \\ Rosenstiel School of Marine and Atmospheric Sciences, University of Miami, Miami, Florida \\ YOCHANAN KUSHNIR \\ Lamont-Doherty Earth Observatory of Columbia University, Palisades, New York \\ Amy Clement \\ Rosenstiel School of Marine and Atmospheric Sciences, University of Miami, Miami, Florida \\ Ed Cook, NaOmi Naik, And Jennifer Miller \\ Lamont-Doherty Earth Observatory of Columbia University, Palisades, New York
}

(Manuscript received 1 August 2007, in final form 19 February 2008)

\begin{abstract}
The possible role that tropical Pacific SSTs played in driving the megadroughts over North America during the medieval period is addressed. Fossil coral records from the Palmyra Atoll are used to derive tropical Pacific SSTs for the period from A.D. 1320 to A.D. 1462 and show overall colder conditions as well as extended multidecadal La Niña-like states. The reconstructed SSTs are used to force a 16-member ensemble of atmosphere GCM simulations, each with different initial conditions, with the atmosphere coupled to a mixed layer ocean outside of the tropical Pacific. Model results are verified against North American tree ring reconstructions of the Palmer Drought Severity Index. A singular value decomposition analysis is performed using the soil moisture anomaly simulated by another 16-member ensemble of simulations forced by global observed SSTs for 1856-2004 and tree ring reconstructions of the Palmer Drought Severity Index for the same period. This relationship is used to transfer the modeled medieval soil moisture anomaly (relative to the modern simulation) into a model-estimated Palmer Drought Severity Index. The model-estimated Palmer Drought Severity Index reproduces many aspects of both the interannual and decadal variations of the tree ring reconstructions, in addition to an overall drier climate that is drier than the tree ring records suggest. The model-estimated Palmer Drought Severity Index simulates two previously identified "megadroughts," A.D. 1360-1400 and A.D. 1430-60, with a realistic spatial pattern and amplitude. In contrast, the model fails to produce a period of more normal conditions in the early fifteenth century that separated these two megadroughts. The dynamical link between tropical SSTs and the North American megadroughts is akin to that operating in modern droughts. The model results are used to argue that the tropical Pacific played an active role in driving the megadroughts. However, the match between simulated and reconstructed hydroclimate is such that it is likely that both the coral-reconstructed SST anomalies contain significant errors and that SST anomalies in other basins also played a role in driving hydroclimate variations over North America during the late medieval period.
\end{abstract}

\footnotetext{
* Lamont-Doherty Earth Observatory Contribution Number 7199.
}

Corresponding author address: Dr. Richard Seager, Lamont-Doherty Earth Observatory of Columbia University, Palisades, NY 10964.

E-mail: seager@1deo.columbia.edu

DOI: $10.1175 / 2008 J C L I 2170.1$

(C) 2008 American Meteorological Society 


\section{Introduction}

In 1929 and 1935 the archaeologist A. E. Douglass reported on the first efforts to date the occupation times of the abandoned Indian settlements in the Four Corners region of the American Southwest (Douglass 1929, 1935). Douglass linked together tree ring records from living trees, beams within occupied Indian structures, and beams from abandoned settlements. This provided precise dates for when the trees were felled for use as building material and identified the period of occupation as the early part of the last millennium. In the process, Douglass (1929) identified a period of unusually narrow tree ring widths in the last two decades of the thirteenth century, which he referred to as the "Great Drouth [sic]" and speculated on how this might have impacted Indian societies. This was the first account of what has since been referred to as the "medieval megadroughts," a series of intense and long-lived droughts that afflicted western North America, from the plains to the Pacific and from present-day Mexico to present-day Canada, between about A.D. 800 and A.D. $1500 .{ }^{1}$ Later, Dillehay (1974) also identified the late-thirteenth-century drought based on the small number of bison bones in Indian hunting camp sites in the southern plains that date to that time.

Recent research has extended our knowledge of the megadroughts. Stine (1994) dated tree stumps submerged in rivers and lakes in the Sierra Nevada of California to identify long periods of medieval aridity during which the trees lived before dying when waters rose at the termination of the megadroughts. Stine's aridity periods are roughly the tenth and eleventh centuries and the thirteenth and early fourteenth centuries. Woodhouse and Overpeck (1998) summarized widespread evidence, including paleolake levels, tree rings, submerged tree stumps, sand-dune activity, etc., that substantiated widespread aridity in medieval times over the American West. The megadroughts then came into much better focus with the development of a gridded network of annual tree ring data (Cook and Krusic 2004; Cook et al. 2004). The reconstructions of summer Palmer Drought Severity Index (PDSI) showed an overall drier period in the West from roughly A.D. 800

\footnotetext{
${ }^{1}$ The term megadrought has no precise definition, but best refers to droughts that have an intensity at least equivalent to modern multiyear droughts, but that lasted longer than the several years to a decade thereof (see Herweijer et al. 2007). Here we adopt the commonly used European historian's definition of the medieval period as lasting until the later half of the fifteenth century and terminating with the Turkish capture of Constantinople, the rise of the Tudors in England, or some such event.
}

into the fifteenth century, followed by wetter centuries and some drying in the historical period. Herweijer et al. (2007) analyzed the records in more detail to show that the period of medieval aridity was made up of a succession of multidecadal droughts with spatial patterns that were very similar to modern multiyear droughts (such as the Dust Bowl, the 1950s, or the three mid- to late-nineteenth-century droughts), with comparable magnitudes in any one year, but with persistence that has not been seen since. Stahle et al. (2007) has used the tree ring reconstructions to identify latefourteenth-century and middle-fifteenth-century megadroughts that had continental-scale impacts.

The causes of the medieval megadroughts are not yet known, although there has been ample speculation. However, buoyed by the availability of instrumental sea surface temperature (SST) data that extends back to 1856 , climate modelers have recently attributed the 1930s Dust Bowl drought to small variations of tropical Pacific and tropical Atlantic SST anomalies (SSTAs; Schubert et al. 2004b,a) on the basis that atmosphere models forced by the observed SSTs produce a drought over North America during this decade. Seager et al. (2005b) and Herweijer et al. (2006) have also used SSTforced atmosphere model simulations to argue that all of the major historical droughts from 1856 to 2000 were forced by tropical SST variations, with the Pacific as the driver. Hoerling and Kumar (2003) and Seager (2007) have made much the same case for the 1998-2002 period of the most recent drought. It is La Niña-like SST anomalies that force drought in western North America, and at similar latitudes in both hemispheres and at almost all longitudes, with warm subtropical North Atlantic SST anomalies appearing to play a supporting role (Schubert et al. 2004b; Seager 2007; Seager et al. 2008).

While it is clear that the models do not reproduce the observed droughts with utter fidelity, in particular, the Dust Bowl drought in all models is too far south of the observed one and did not impact the northern Rocky Mountain states and the Northwest, as observed (Seager et al. 2008), the case is compelling that the historical droughts were part of global hydroclimate anomalies that were orchestrated in the tropics. The similar spatial patterns of the modern and medieval megadroughts suggest that they may have had similar origins, that is, that the tropical Pacific became La Niña-like for long periods and, perhaps, there was also a warmer Atlantic too, a case made by Seager et al. (2007a). This contention draws some support from discontinuous reconstructions of tropical Pacific SSTs from corals that suggest colder conditions during the medieval period (Cobb et al. 2003) and from a pattern of global medi- 
eval hydroclimate that is best explained by a combination of a La Niña-like state with a warm North Atlantic (and a positive North Atlantic Oscillation; Seager et al. 2007a).

Past intensified aridity is of interest because projections of twenty-first-century climate with coupled general circulation models (GCMs) forced by projected changes in radiative forcing show widespread subtropical drying becoming well established early in the current century (Seager et al. 2007b). Southwestern North America is one region that dries. This has been attributed to an overall warming of the surface and atmosphere that 1) intensifies the atmospheric hydrological cycle, making wet areas wetter and dry areas drier, and 2) causes the Hadley cell to expand poleward and the storm tracks to shift poleward, which together cause a poleward expansion of the subtropical dry zones (Held and Soden 2006; Lu et al. 2007; Seager et al. 2007b). In the model projections the drying is not related to any pattern of tropical SSTs and, hence, appears potentially mechanistically distinct from the medieval droughts.

The idea that back-to-back, persistent, multidecadal droughts over a period of centuries can occur for mechanisms distinct from those operating in model projections of future drying is concerning. For example, the medieval period was supposedly a time of higher solar irradiance, weaker volcanism (Crowley 2000), and colder tropical Pacific SSTs (Cobb et al. 2003) than in the subsequent centuries that had warmer tropical $\mathrm{Pa}-$ cific SSTs (Cobb et al. 2003) and lesser aridity over the West (Cook et al. 2004). Positive radiative forcing has been linked to a La Niña-like tropical Pacific response within intermediate models (Clement et al. 1996; Mann et al. 2005; Emile-Geay et al. 2007). However, coupled GCMs do not, in general, respond in this way to rising greenhouse gases (Collins 2005; Vecchi et al. 2006; Vecchi and Soden 2007). This could mean that either (i) coupled GCMs are missing a fundamental response of the tropical Pacific to radiative forcing, (ii) the tropical Pacific climate system responds to solar and greenhouse gas forcing in different ways, or (iii) the medieval state of the tropical Pacific may be the result of internal variability of the climate system on multicentennial time scales, of which we currently have no understanding whatsoever. All three of these possibilities are sobering because they reveal a basic lack of understanding of recent climate change, the ability of models to reproduce these, and, hence, concerns regarding the reliability of future climate projections.

These considerations make clear the importance of better understanding the medieval megadroughts, their global context, and causes. Are they either past analogs of projected future aridity, both a response to positive radiative forcing? Alternatively, did they arise as a response to solar and volcanic forcing, mediated by the tropical Pacific atmosphere-ocean system, which is different from the projected future response to greenhouse gas forcing? Or, did they arise from processes hitherto unknown? We do not pretend to answer all of these questions here and will just test the idea that tropical Pacific SSTs were an important driver of increased medieval aridity. This is possible because of the development of coral-based reconstructions of tropical Pacific SSTs that provide continuous records for discrete intervals of the medieval period (Cobb et al. 2003) and that have a broad consistency with other tropical Pacific ocean proxies (Graham et al. 2007; Seager et al. 2007a). After the work described here was completed, a high-resolution $\mathrm{Mg} / \mathrm{Ca}$-based record of SST since A.D. 1200 from the Cariaco Basin was published (Black et al. 2007), which could probably be used to reconstruct from tropical to subropical Atlantic SSTs. However, here we focus on the possible role of the tropical Pacific while recognizing the potential importance of Atlantic SST anomalies in both forcing drought and offsetting Pacific forcing. Hence, here we will undertake the following:

1) reconstruct tropical Pacific SSTs from available coral records covering A.D. 1320-1463 (Cobb et al. 2003),

2) force an ensemble of atmosphere GCM simulations with the reconstructed SSTs,

3) use an ensemble of instrumental SST-forced simulations for the 1856-2004 period to develop a relationship between modeled soil moisture and tree ring summer PDSI,

4) apply this relationship to the modeled soil moisture for A.D. 1320-1462 to create model estimates of summer PDSI, and

5) compare the model-estimated summer PDSI with that reconstructed from tree ring records.

This work adds to that of Graham et al. (2007), who forced an atmosphere GCM with idealized patterns of SST chosen to match proxy records from the tropical Pacific and demonstrated that these led to drought conditions in southwest North America. Here we use a 143-yr-long proxy SST reconstruction as the climate model forcing and conclude that tropical Pacific SSTs played an important role in forcing the medieval megadroughts. The agreement between modeled and reconstructed hydroclimate is, however, limited and, even though we expect there to be errors in the tropical Pacific SST reconstruction, this suggests the possibility that SSTs in other ocean basins also played a role. 


\section{Reconstructing tropical Pacific SSTs from coral data}

Here we use high-resolution oxygen isotope data taken from fossil corals on the Palmyra Atoll $\left(6^{\circ} \mathrm{N}\right.$, $160^{\circ} \mathrm{W}$; see Cobb et al. 2003) to reconstruct past SSTs. Because of the central location of the Palmyra Atoll, the fossil coral records capture the interannual variability associated with El Niño and the Southern Oscillation as well as lower-frequency variability. First, we develop a relation between the modern SST record and monthly oxygen isotope ratios from modern corals for the period of 1886-1998. The SST data used are from Kaplan et al. (1998).

Monthly anomalies of SST and $\delta^{18} \mathrm{O}$ were formed by removing the long-term monthly means from each calendar month's mean. The $\delta^{18} \mathrm{O}$ anomalies were then separated into high- and low-pass components. The filtering technique comes from Zhang et al. (1997), where successive 25- and 37-month filters are applied to the $\delta^{18} \mathrm{O}$ time series to get low-pass-filtered $\delta^{18} \mathrm{O}$. The highpass-filtered $\delta^{18} \mathrm{O}$ is simply the unfiltered $\delta^{18} \mathrm{O}$ minus the low-pass-filtered data. Linear regression using least squares was then used to derive the spatial patterns of SST anomalies associated with high- and low-passfiltered $\delta^{18} \mathrm{O}$ anomalies. One result inherent to the least squares regression process is that reconstructions have reduced variance relative to the original record. To address this issue we incorporate two indices used in the literature to describe interannual and decadal variability of SST. A tropical Pacific index $\left(20^{\circ} \mathrm{N}-20^{\circ} \mathrm{S} 160^{\circ} \mathrm{E}-\right.$ $80^{\circ} \mathrm{W}$ ) from Zhang et al. (1997) was used to characterize the low-frequency component of the SST reconstruction and low-pass-filtered SSTAs, while the highpass-filtered Niño-3.4 index $\left(5^{\circ} \mathrm{S}-5^{\circ} \mathrm{N}, 170^{\circ}-120^{\circ} \mathrm{W}\right)$ was used to characterize the interannual component. To inflate the variance of the reconstructed SST components, we normalized the reconstructed time series to match the variance of the observations. The components of the modern SST reconstruction are as follows:

$$
\begin{aligned}
\operatorname{SST}_{\mathrm{LP}}(x, y, t)= & \alpha(x, y) \times \delta^{18} \mathrm{O}_{\mathrm{LP}}(t) \times N_{\mathrm{TPI}} \\
\operatorname{SST}_{\mathrm{HP}}(x, y, t)= & \beta(x, y) \times \delta^{18} \mathrm{O}_{\mathrm{HP}}(t) \times N_{N 34} \\
\operatorname{SST}_{\text {mod }}(x, y, t)= & \operatorname{SST}_{\text {climatology }}(x, y, t)+\operatorname{SST}_{\mathrm{LP}}(x, y, t) \\
& +\operatorname{SST}_{\mathrm{HP}}(x, y, t) .
\end{aligned}
$$

Here, $\delta^{18} \mathrm{O}_{\mathrm{LP} / \mathrm{HP}}$ is the low-/high-pass-filtered $\delta^{18} \mathrm{O}$ anomaly derived from modern coral data, $\alpha$ and $\beta$ are the regression coefficients, and $N_{\mathrm{TPI} / N 34}$ is the constant used to normalize the low-/high-pass variance and equals 1.2 and 1.6, respectively.

We then apply these relationships to the $\delta^{18} \mathrm{O}$ from the fossil coral record of Cobb et al. (2003) that covers the A.D. $1320-1462$ period. The medieval SST reconstruction is derived from

$$
\operatorname{SST}_{\mathrm{LP} 14}(x, y, t)=\alpha(x, y) \times\left[\delta^{18} \mathrm{O}_{\mathrm{LP} 14}(t)+\mu_{14}\right] \times N_{\mathrm{TPI}},
$$

$$
\begin{aligned}
\operatorname{SST}_{\mathrm{HP} 14}(x, y, t)= & \beta(x, y) \times \delta^{18} \mathrm{O}_{\mathrm{HP} 14}(t) \times N_{N 34} \\
\operatorname{SST}_{14}(x, y, t)= & \operatorname{SST}_{\text {climatology }}(x, y, t)+\operatorname{SST}_{\mathrm{LP} 14}(x, y, t) \\
& +\operatorname{SST}_{\mathrm{HP} 14}(x, y, t),
\end{aligned}
$$

where $\delta^{18} \mathrm{O}_{\mathrm{LP} 14}$ and $\delta^{18} \mathrm{O}_{\mathrm{HP} 14}$ are the low- and highpass-filtered $\delta^{18} \mathrm{O}$ anomalies from the A.D. 1320-1462 coral, and $\mu_{14}$ is the difference in the long-term means of the fossil and modern $\delta^{18} \mathrm{O}$ coral records, which is here assumed to be related to a change in SST that has the low-frequency pattern and also has the variance adjustment applied to it. $^{2}$

The time series of the annual mean tropical Pacific SST averaged over $5^{\circ} \mathrm{S}-5^{\circ} \mathrm{N}, 180^{\circ}-90^{\circ} \mathrm{W}$ and for the A.D. 1320-1462 period minus the 1886-1998 climatology is shown in Fig. 1. Despite a few warm intervals, this medieval period was overall colder than the modern period and there were some very extended, uninterrupted, La Niña-like events, such as in the midfourteenth and early fifteenth century and another period of strong cold SST anomalies in the late fourteenth century that was, however, frequently interrupted by single warm years. The variance of tropical Pacific SSTs during this period is less than that in the modern period, which follows from the weaker variance of coral $\delta^{18} \mathrm{O}$ (see Cobb et al. 2003, their Fig. 6).

\section{Models, modeling approach, and method of verification against tree ring data}

\section{a. Model used}

The atmosphere model used here is the Community Climate Model, version 3 (CCM3) of the National Center for Atmospheric Research (NCAR), which is run at T42 resolution with 18 vertical levels (Kiehl et al. 1998). This model has been shown in a series of prior publications that it is capable of simulating all of the six droughts within the instrumental period with, in most cases, realistic magnitudes and patterns when forced by observed SSTs, with the tropical Pacific SSTs being the dominant driver (Seager et al. 2005b; Huang et al. 2005; Herweijer et al. 2006; Cook et al. 2007; Seager 2007);

\footnotetext{
${ }^{2}$ It can be argued whether or not the variance adjustment should be applied to the mean $\delta^{18} \mathrm{O}$ offset. Regardless, this will increase the mean change in tropical Pacific SST by a factor of 1.2 and will not impact the variability within the period.
} 


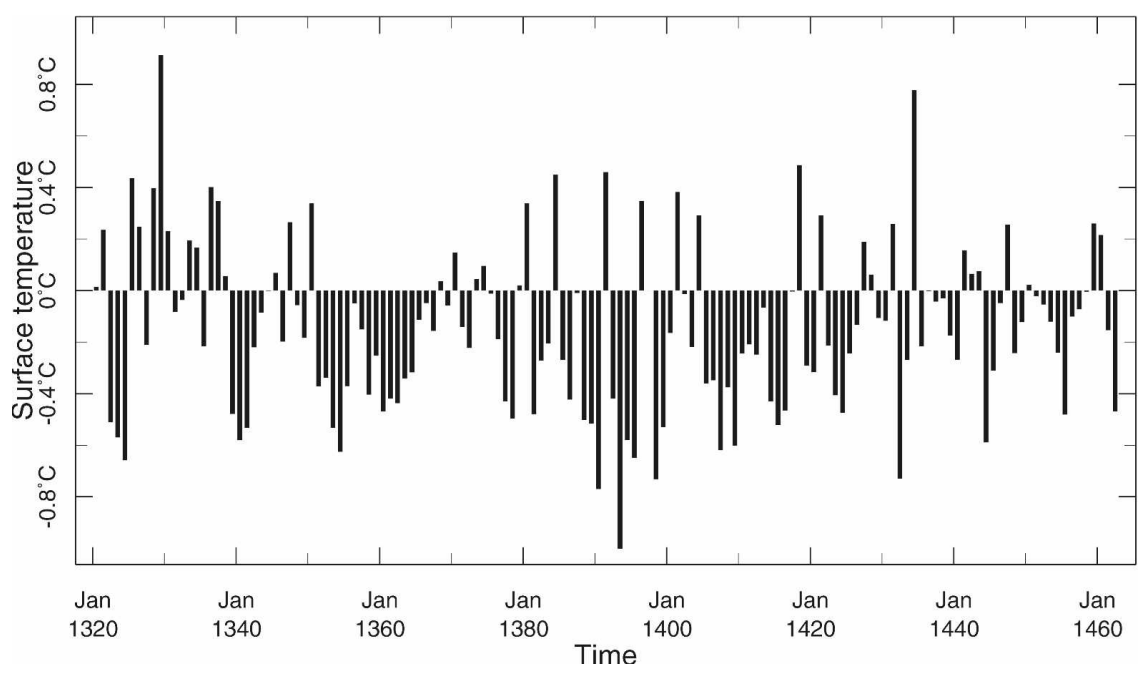

FIG. 1. The coral-reconstructed tropical Pacific SST index $\left(5^{\circ} \mathrm{S}-5^{\circ} \mathrm{N}, 180^{\circ}-90^{\circ} \mathrm{W}\right)$ for the A.D. 1320-1462 period minus the 1886-1998 climatology.

Seager et al. (2008) provide a detailed account of the model's successes and failures in the particular case of the Dust Bowl drought.

The model simulations analyzed here are as follows:

1) A 16-member ensemble from 1856 to 2004, each with different initial conditions, with global SST forcing is analyzed. The SST data used for the forcing are the Hadley Centre Global Sea Ice and SST (HadISST) data outside of the tropical Pacific (Rayner et al. 2003) merged with tropical Pacific $\left(20^{\circ} \mathrm{S}-20^{\circ} \mathrm{N}\right)$ SSTs from Kaplan et al. (1998). This choice was motivated by the earlier start time of the Kaplan data. This is the Global Ocean Global Atmosphere (GOGA) ensemble.

2) A 16-member ensemble from A.D. 1320 to A.D. 1462 forced by the tropical Pacific $\left(20^{\circ} \mathrm{S}-20^{\circ} \mathrm{N}\right)$ SSTs, reconstructed as described in the previous section, and coupled to a uniform 75-m-deep mixed layer ocean elsewhere is also analyzed. The mixed layer ocean contains a specified seasonally varying " $q$ flux," which ensures that the computed SST, when run with modern SSTs in the tropical Pacific, remains close to the modern climatology. Departures of the SST outside of the tropical Pacific from that climatology are due to the influence of the specified medieval tropical Pacific SSTs communicated through the atmosphere and into the ocean by surface fluxes. This is the Pacific Ocean Global Atmosphere One Layer (POGA-1L) ensemble.

The POGA-1L modeling design is based on the recognition that variations in tropical Pacific SSTs force changes in atmospheric circulation that force SST anomalies elsewhere, such as in the North Pacific and tropical Atlantic Oceans (e.g., Alexander et al. 2002). Remote ENSO-forced SST anomalies can then themselves force atmospheric circulation anomalies. For example, Seager (2007) discusses the direct impact of tropical Pacific SST anomalies on the North American hydroclimate as well as the impact of SST anomalies in the subtropical North Atlantic that were themselves forced from the tropical Pacific. The POGA-1L modeling method is designed to capture this "net" effect of tropical Pacific SST anomalies.

\section{b. Relating modeled soil moisture anomalies to tree ring-reconstructed PDSI}

The tree ring validation is the reconstruction of summer PDSI. The reconstructed PDSI is based on the relationship between the tree ring records and instrumental PDSI (van der Schrier et al. 2006) for the period from 1928 to 1978 . The instrumental PDSI uses a simple surface hydrology model forced by observed precipitation and surface air temperature, with PDSI being a measure of the modeled soil moisture within a shallow upper layer on the order of $1 \mathrm{~m}$ deep (Palmer 1965). The data used here are an update of the North American drought atlas of Cook and Krusic (2004). The original data had 835 tree ring chronologies, whereas the update has 1825 , with the number before A.D. 1300 going up from 89 to 195, which allowed for better coverage of the medieval period, especially in the Northwest, Colorado, and New Mexico.

We could compute PDSI from the atmosphere model ensembles. However, the atmosphere model computes soil moisture directly, with a more sophisticated soil 
Filtered PDSI Anom V2a(colors) and GOGA Soil Moisture Anom (contours), Mode $194 \%$
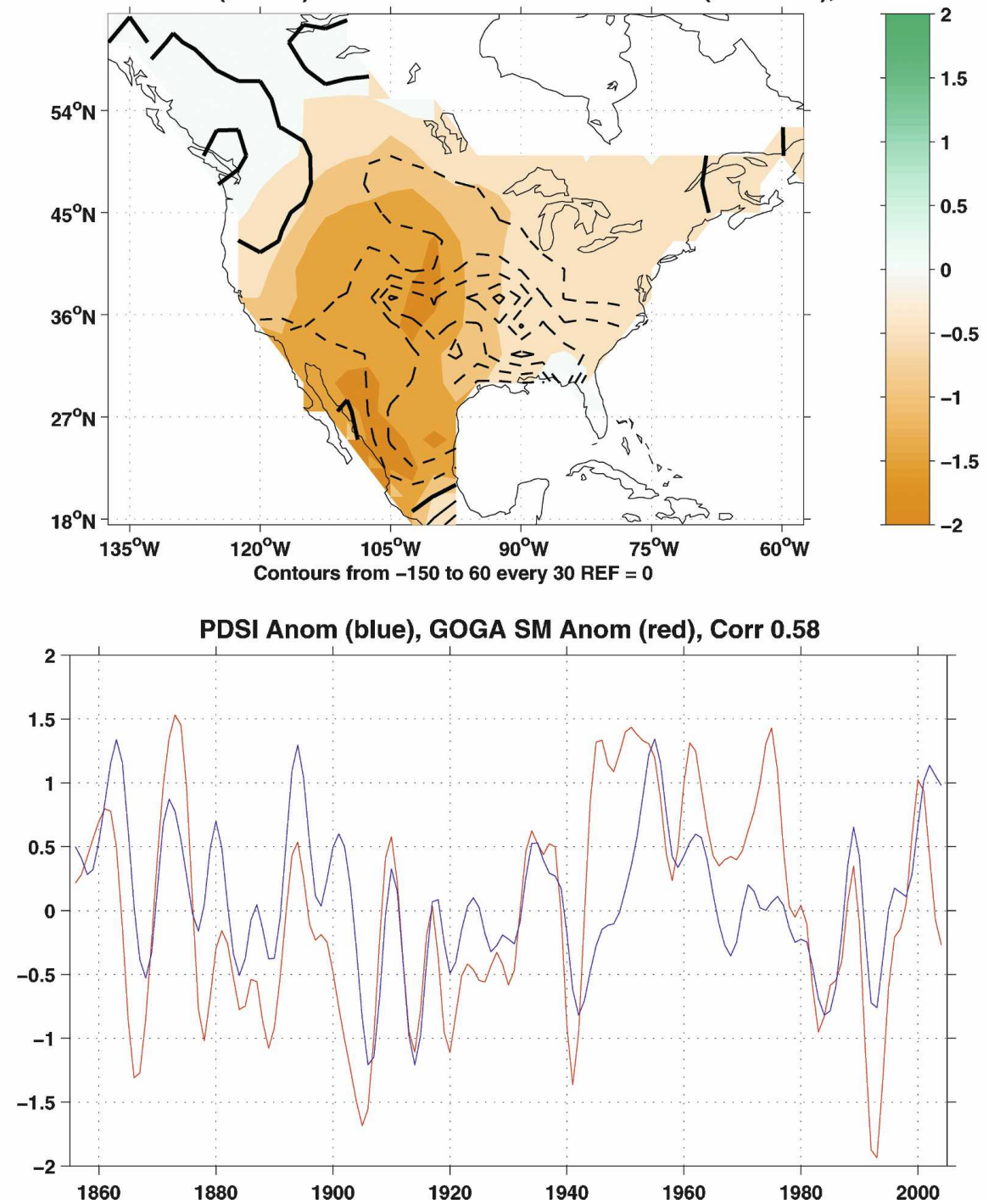

FIG. 2. Results of an SVD analysis of tree ring-reconstructed PDSI and soil moisture anomalies from the ensemble mean of the GOGA model forced with global observed SSTs. The analysis was performed on the period from 1856 through 2004. (top) The spatial patterns of tree ring PDSI and model soil moisture and (bottom) the two time series of the patterns that correlate with a coefficient of 0.58 are shown. PDSI and soil moisture are dimensionless quantities.

hydrology model than within the PDSI calculation, and also accounts for the influence of vegetation on evapotranspiration and effects of variations in radiation and snow cover, etc. It does not make sense to degrade the model by just using modeled temperature and precipitation to compute PDSI. Hence, we use another approach. We perform singular value decomposition (SVD) between the GOGA ensemble mean model soil moisture anomaly (integrated over the top $0.7 \mathrm{~m}$, a dimensionless measure of kilograms of water per kilogram of soil) and the tree ring PDSI over the overlapping period (1856-2004). Both datasets had a 6-yr low- pass filter applied to them first to emphasize variations on longer-than-interannual time scales. The SVD procedure decomposes fields that vary in space and time into spatial patterns of model soil moisture and tree ring PDSI and time series that describe their evolution with time. SVD analysis identifies pairs of patterns that maximize the covariance between the time evolutions of the two fields (Bretherton et al. 1992).

For the 1856-2004 period, the results for the first pair are shown in Fig. 2. The tree ring PDSI pattern shows anomalies of the same sign across the United States and into Mexico, with maximum values in the interior West. 
The model soil moisture pattern is centered to the east of the PDSI pattern [which may be understandable in terms of the west-to-east increase in climatological soil moisture, a difference in mean climate for which PDSI attempts to account (Palmer 1965)], and also extends into Mexico and covers most of the United States. The lower panel shows time series of the two patterns (note that positive values refer to positive values of the spatial patterns and, therefore, drought) that have notable correlation at multiyear to decadal time scales, although significant differences occur between the late 1940s and late 1970s.

The fraction of the total 6-yr low-pass-filtered variances of the ensemble mean soil moisture and the tree ring PDSI explained by the respective patterns from the first pair of the SVD analysis are shown in Fig. 3. For the model the explained variance reaches close to one near the gulf coast, indicating that almost all of the ensemble mean (i.e., SST forced) variance in that region is contained within this one spatial pattern. The first-mode pattern explains a large part of the total variance across the central United States and into Mexico. The first mode of the tree ring PDSI explains up to $70 \%$ of the total variance in the interior Southwest of the United States and in north-central Mexico, with lesser values away from that region.

This analysis suggests that the first SVD pair contains most of the observed or modeled variance. The remaining variance is explained by a series of additional patterns that each explain only small parts of the total variance and are not considered here. Instead, we will use the first pair to move between modeled soil moisture and model-estimated PDSI, noting that this procedure also introduces a possible pattern correction.

\section{Comparison of model-reconstructed PDSI and tree ring PDSI for the West: A.D. 1320-1462}

To compare the modeled soil moisture and tree ringreconstructed PDSI for the medieval period, we begin with the ensemble mean soil moisture. This is projected onto the pattern shown in Fig. 2a (contours) to obtain a time series that describes the time evolution of the amplitude of the pattern. A regression of the time series in Fig. $2 b$ is then used to go from the time series of the amplitude of the soil moisture pattern to the time series of the amplitude of the PDSI pattern. Multiplying this time series by the spatial pattern of PDSI shown in Fig. 2a (colors) provides a time and space field that is the model-estimated PDSI.

Figure 4 shows both the tree ring-reconstructed and model-estimated PDSI averaged over the Southwest $\left(25^{\circ}-45^{\circ} \mathrm{N}, 125^{\circ}-95^{\circ} \mathrm{W}\right)$ for the entire period of the model simulation. The two standard deviation limits of the model ensemble are also shown as the shading. The agreement between these time series is limited, but the following number of points can be made:

1) The correlation coefficient between the tree ringreconstructed and model-estimated PDSI is 0.33 , which, though not very impressive, is high considering that (i) the SST reconstruction is based on coral records at a single point, (ii) the coral record contains dating errors of up to a few years, and (iii) we ignore the possible influence of SSTs outside of the tropical Pacific that are not generated by the tropical Pacific.

2) The preponderance of negative values, that is, drought, throughout the $143 \mathrm{yr}$ is clear in both the model and proxy reconstructions, but the modelestimated mean PDSI averaged over the entire period of -0.91 is considerably in excess of the proxyreconstructed value of -0.28 .

3) Despite dating errors, there are relatively short time-scale maxima and minima in the tree ringreconstructed and model-estimated PDSI that coincide.

4) There are multidecadal variations of tree ringreconstructed PDSI that are not well captured by the model (e.g., the wet spell from A.D. 1400 to A.D. 1430).

Overall, the results in Fig. 4 suggest that the colder tropical Pacific was an important driver of medieval aridity in the West, and that it also influenced the yearto-year and decade-to-decade variations of aridity within the period. However, unlike simulations of the nineteenth- and twentieth-century climate, when the observed record almost always falls within the ensemble spread (Seager et al. 2005b), there are periods when the observed record lies outside the range of PDSI that can be accounted for by the combination of SST-forced atmosphere model and SVD correction of model soil moisture to PDSI. This discrepancy could be accounted for by errors in the amplitudes, timing, and spatial structure of the SST variations that are used to force the model (which have to be large) or come from the neglect of SST variations elsewhere, such as the Atlantic Ocean.

\section{Comparison of two modeled and tree ring-reconstructed megadroughts}

The tree ring-reconstructed PDSI indicates two extended periods of near-uninterrupted aridity within the A.D. $1320-1462$ period. These are, roughly, A.D. 1360 1400 and A.D. $1430-60$. The first period contains within 

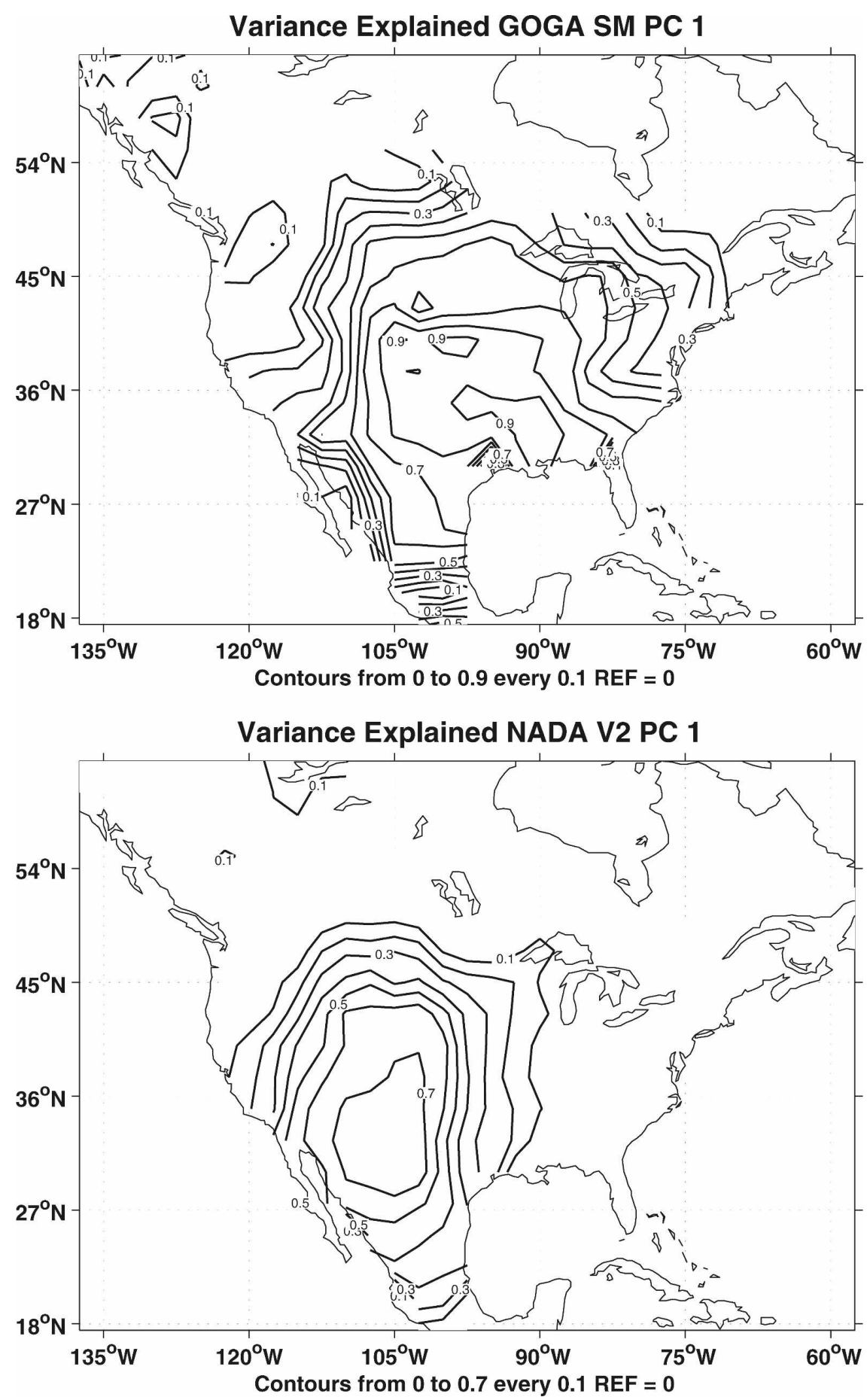

FIG. 3. The fraction of the total variance of (top) GOGA ensemble mean soil moisture and (bottom) tree ring-reconstructed PDSI explained by the first pair of patterns from the SVD analysis. Results cover the period from 1856 through 2004.

it the A.D. 1360-82 drought identified by Herweijer et al. (2007) and the A.D. 1387-1402 "western megadrought" identified by Stahle et al. (2007). The latter period includes the earlier part of the "fifteenthcentury megadrought" identified by Stahle et al. (2007).
The tree ring-reconstructed droughts covered most of the modern-day United States (Fig. 5). The drought neither impacted the far-northeast North America nor the Pacific Northwest, and the later drought actually had notably wetter climates in these regions as well as 


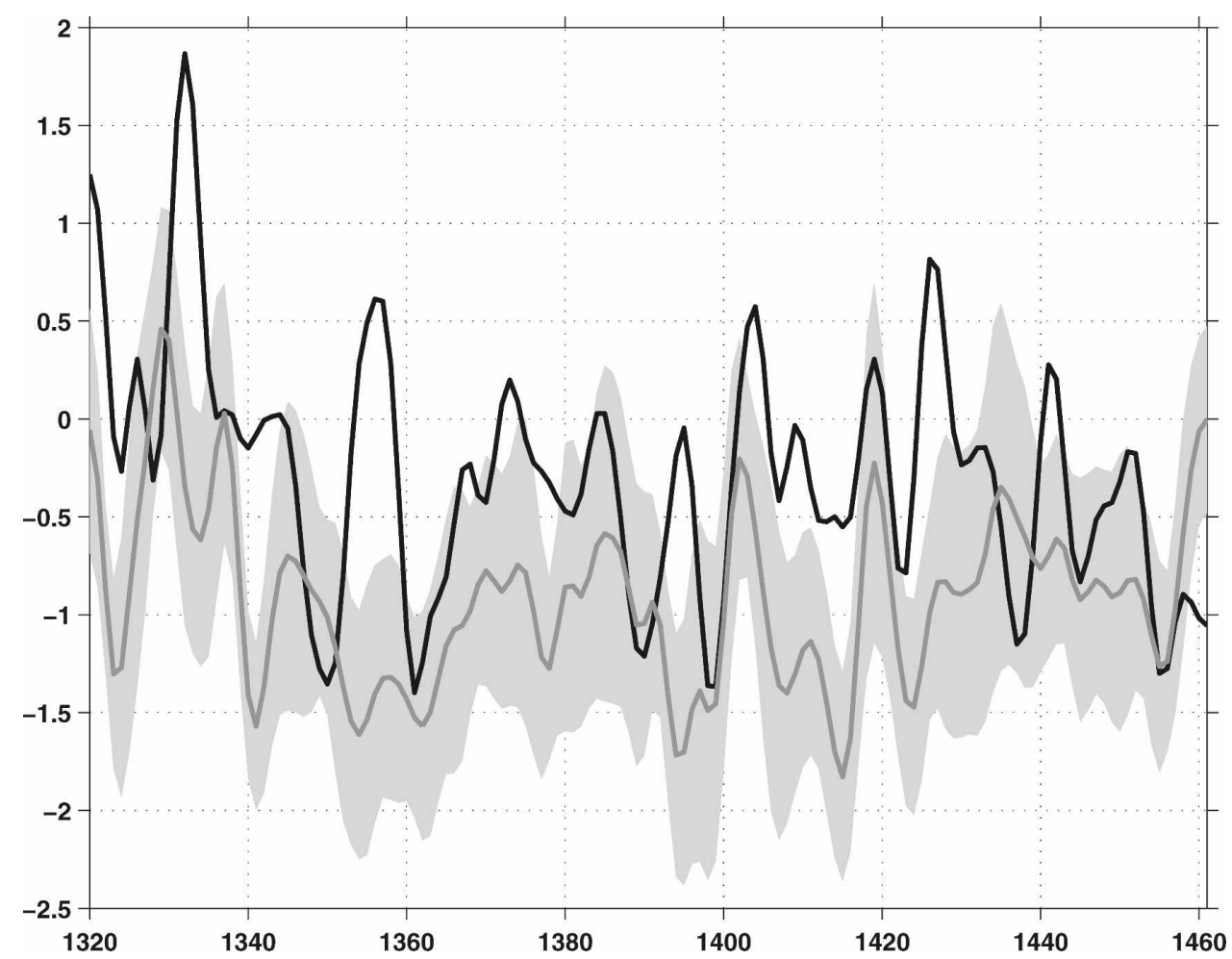

FIG. 4. The tree ring-reconstructed PDSI (black) and the model-estimated PDSI (gray) from the ensemble mean with shading to mark the two standard deviation spread of the 16-member ensemble. All results are 6-yr low-pass filtered to emphasize longer-than-interannual time scales.

in the southwest of modern-day Canada. Maximum drying is centered in the Mississippi valley for the earlier drought and both there and in the interior West for later drought. The tree ring records do not cover Mexico during these periods. The modeled soil moisture anomaly (Fig. 5), relative to the model climatology for the modern period, also impacts most of North America, but neither the Northwest nor the Northeast. There is modeled drying in northern Mexico (which cannot be verified). For both droughts the decrease in soil moisture is a maximum in the Lower Mississippi valley. The transfer from the modeled soil moisture anomaly to PDSI, when applied to the modeled medieval soil moisture anomaly, produces an estimated PDSI that shows drying from northern Mexico to Canada and across the continent from west to east (Fig. 5). The model-estimated PDSI depression correctly influences neither the Northeast nor the Northwest and has maxima in the Mississippi valley. However, the strong drying in the interior West in the fifteenthcentury drought is not reproduced in the modeled soil moisture or the model-estimated PDSI.

The comparison between modeled and tree ringreconstructed drought patterns and magnitudes suggests that there was a link between tropical Pacific SSTs and medieval droughts. If the relation between modeled soil moisture and tree ring PDSI is used to estimate medieval PDSI from modeled medieval soil moisture, a quite realistic pattern of medieval PDSI is estimated with reasonable magnitude for these two droughts. This procedure involves both the potential pattern and amplitude corrections to the model response. However, because the model can reasonably explain the amplitude and pattern of the modern (post1856) drought record, the coral-reconstructed cold tropical Pacific SSTs can explain in part, but certainly not entirely, these two medieval megadroughts.

However, the prior identification of these two megadroughts as distinct events was based on the identification of a wetter period in between A.D. 1400 and A.D. 1430. This wet period is also seen in the new tree ringbased proxy PDSI reconstruction shown in Fig. 4. However, the model entirely fails to reproduce this wet period and merges the two megadroughts into a continuous dry period. This most likely implies that either the reconstructed tropical Pacific SSTs for this period are in error or that the wet period was forced by SSTs elsewhere, for example, in the subtropical North Atlantic Ocean. This would require a multidecadal period of cold SSTs in the Atlantic. The $\mathrm{Mg} / \mathrm{Ca}$-based SST recon- 

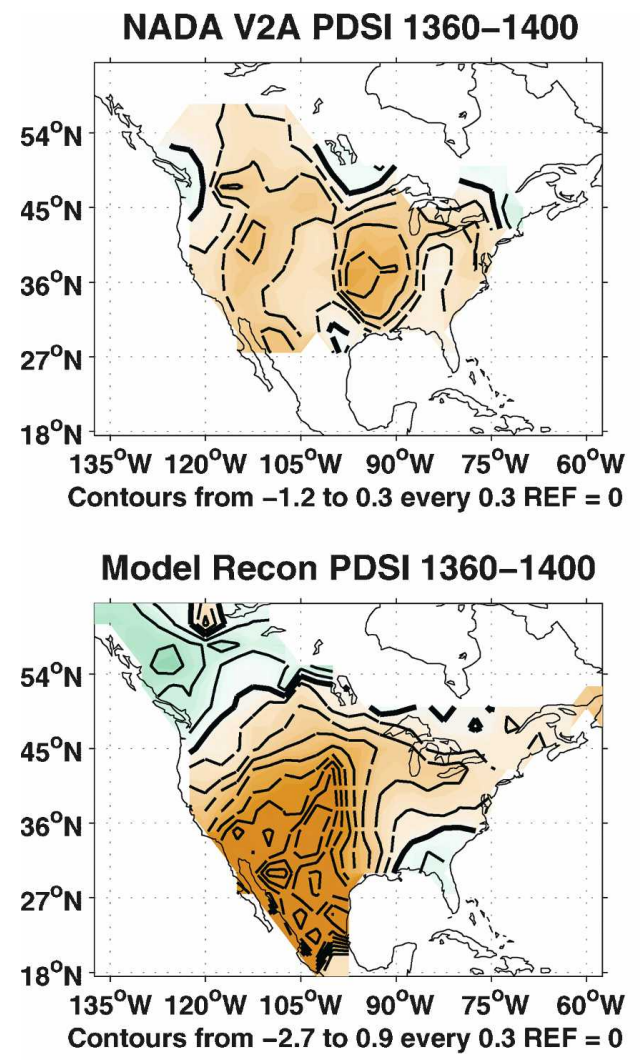

Model Soil Moisture 1360-1400

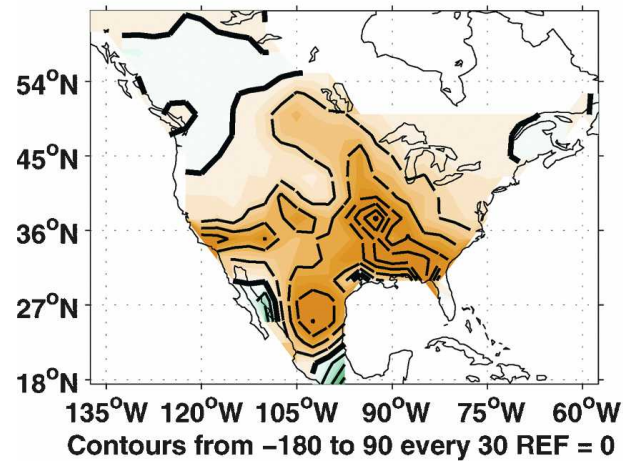

NADA V2A PDSI 1430-1460

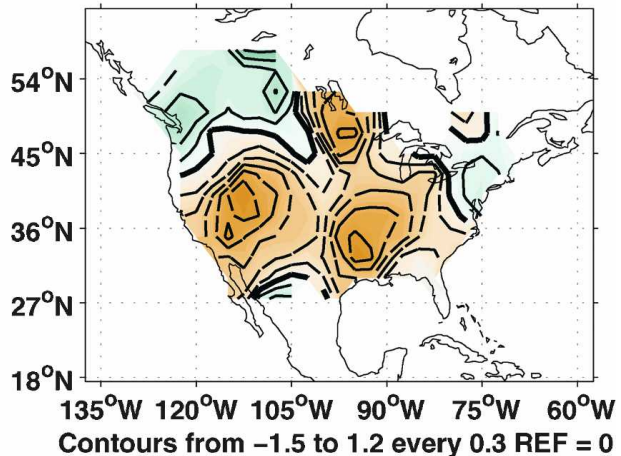

Model Recon PDSI 1430-1460

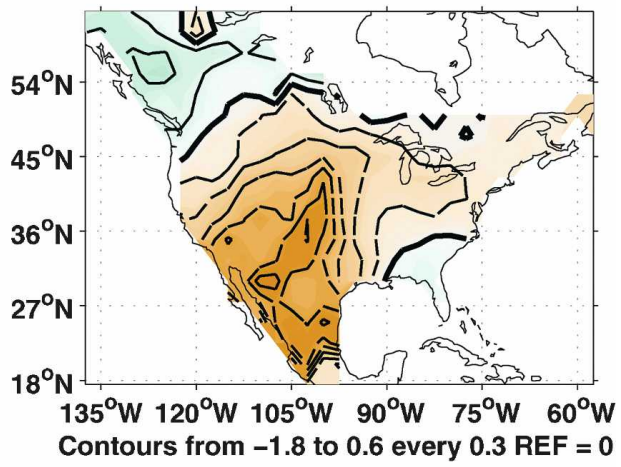

Model Soil Moisture 1430-1460

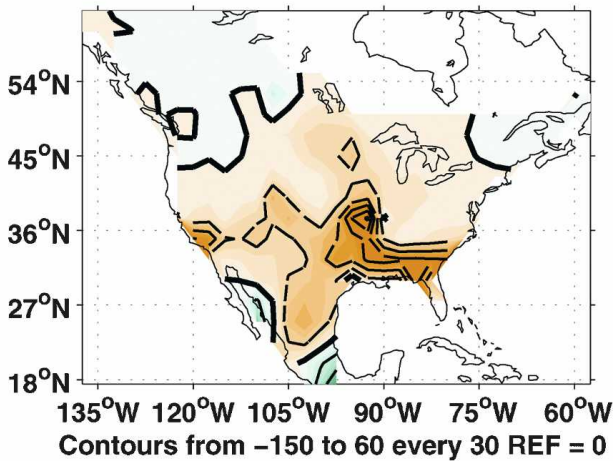

FIG. 5. (top) The tree ring-reconstructed PDSI, (middle) the model-estimated PDSI, and (bottom) the model soil moisture anomaly both from the model ensemble mean for the A.D. 1360-1400 megadrought and the A.D. $1430-60$ period of the mid-fifteenth-century megadrought.

structions from the Cariaco Basin presented by Black et al. (2007) suggest that SSTs are cooler overall than the late twentieth century for the period from A.D. 1200 to the mid-fifteenth century, with the coldest period in the early fifteenth century. If these reconstructions are correct and representative of the subtropical North Atlantic, then they would introduce a tendency to wetter conditions that could offset the impacts of Pacific forcing and account for the model's excess drying in the early fifteenth century.

\section{Dynamics of the medieval tropical Pacific SST-North American megadrought link}

The dynamics that link tropical Pacific SSTs and the modeled North American megadroughts during the medieval period are familiar from studies of observational ENSO-related links (Seager et al. 2005a), modelbased studies of the nineteenth- and twentieth-century droughts (Seager et al. 2005b; Herweijer et al. 2006; Cook et al. 2007), and an attempt at comparing both the 


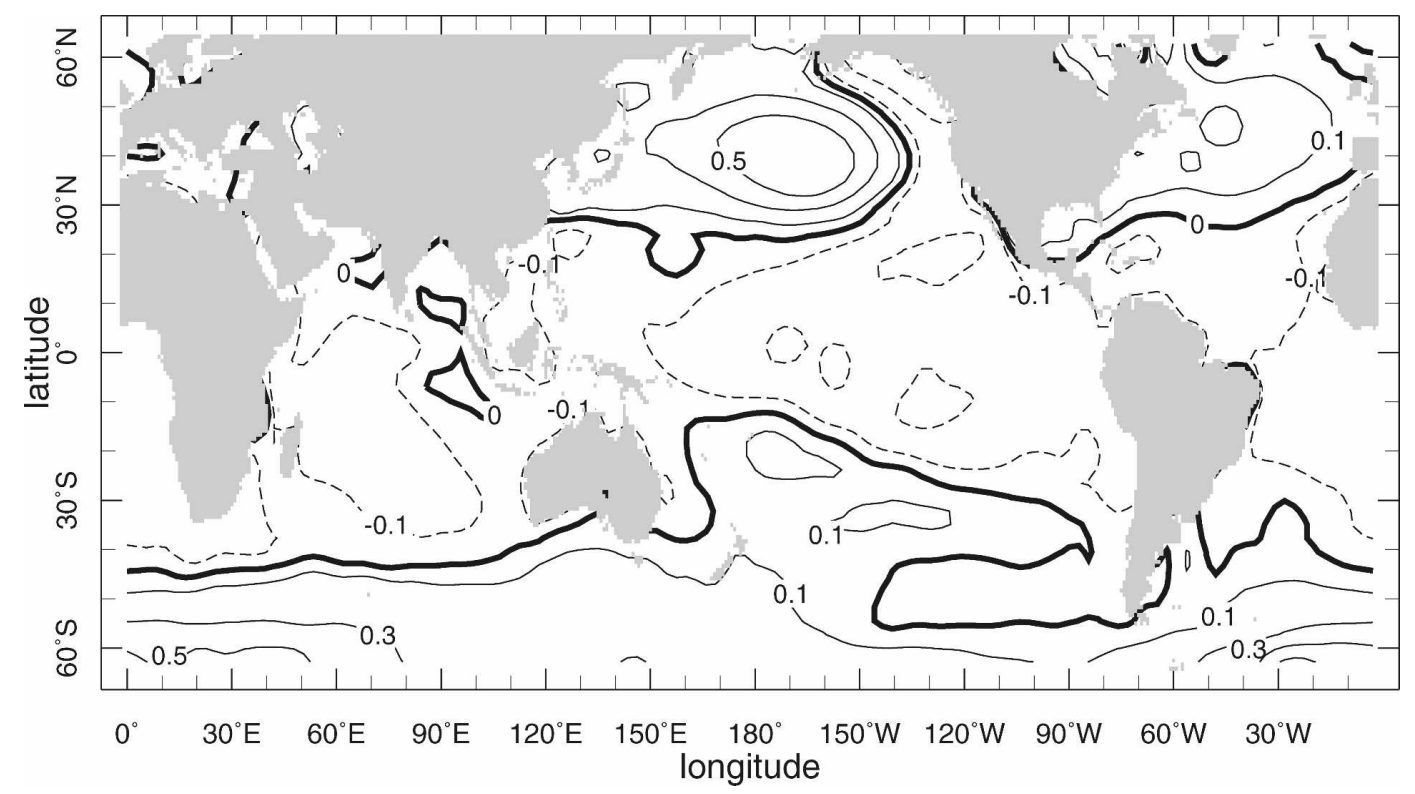

FIG. 6. The difference in SST between the A.D. 1360-1400 and the modern (A.D. 1886-1998) periods as reconstructed from a coral record in the tropical Pacific and computed by the ocean mixed layer model elsewhere as a remote response to the tropical Pacific anomalies. Units are in kelvin.

observed and modeled states for the post-1998 drought (Seager 2007). The basic dynamical setup begins with the SST illustrated in Fig. 6 for the A.D. 1360-1400 period. (Results are similar for the A.D. 1430-60 period, but are less distinct because the SST anomaly was weaker than that during A.D. 1360-1400.) La Niña-like conditions in the tropical Pacific, which are imposed, are clear, with anomalies reaching a fraction of a kelvin, comparable to those during modern droughts. Outside of the tropical Pacific the model ocean mixed layer produces (via surface flux anomalies created as a remote response to the imposed tropical Pacific SST anomalies) cold SST anomalies in the other tropical oceans and along the west coast of the Americas and warm SST anomalies in the extratropical western and central North Pacific Ocean. This pattern is typical of persistent La Niña-like conditions (e.g., Zhang et al. 1997).

In response to the cooler tropical SSTs, relative to the modern-day simulation, the tropical troposphere cools, the zonal mean subtropical jets shift poleward, and, also in the zonal mean, the midlatitudes warm (Fig. 7, top), all of which, again, are expected responses to the persistent La Niña and are dynamically explained in detail by Seager et al. (2003). Consequently, the drying over western North America fits into a global pattern of hydroclimate anomaly as shown in Fig. 8. During the winter half-years (Fig. 8, top) negative regions of change in precipitation $(P)$ minus evaporation $(E)$ extend from the subtropical and midlatitude west Pacific across North American and the Atlantic into the Medi- terranean region, accompanied by upper-tropospheric ridges, as is typical of La Niña events (Seager et al. 2005a). Geopotential heights are low in the tropics, following on from the SST cooling.

In the summer half-year (Fig. 8, bottom), although geopotential heights are low throughout the tropics, there is only a weak tropically forced signal in the extratropics, which is potentially consistent with the weaker mean flow in the summer half-year. In the summer half-year the change in $P-E$ is positive over southern North America, even though the change in $P$ itself is negative (not shown). The soil moisture anomalies are negative in the summer half-year, because they are in the winter half-year, combining to form the annual mean negative soil moisture anomaly shown in Fig. 5. Taken together, this indicates that a reduction of $P-E$ in winter causes a soil moisture reduction that drives both $E$ and, hence, $P$ down in the summers, which is opposed by anomalous atmospheric moisture convergence. This seasonal evolution was also the case in the modeled modern droughts (Seager et al. 2005b; Herweijer et al. 2006; Seager 2007). The annual mean change in $P-E$ (not shown) is zero or weakly negative over North America, indicating that the annual mean reduction of $P$ is largely balanced by a reduction of $E$, and to a lesser extent by reduced runoff.

Transient eddies provide the link between tropical climate changes and midlatitude drying. As explained by Seager et al. (2003), tropical troposphere cooling will cause a poleward-shifted subtropical jet, which, in turn, 
a) $\mathrm{T}$ (colors), $\mathrm{U}$ (contours)
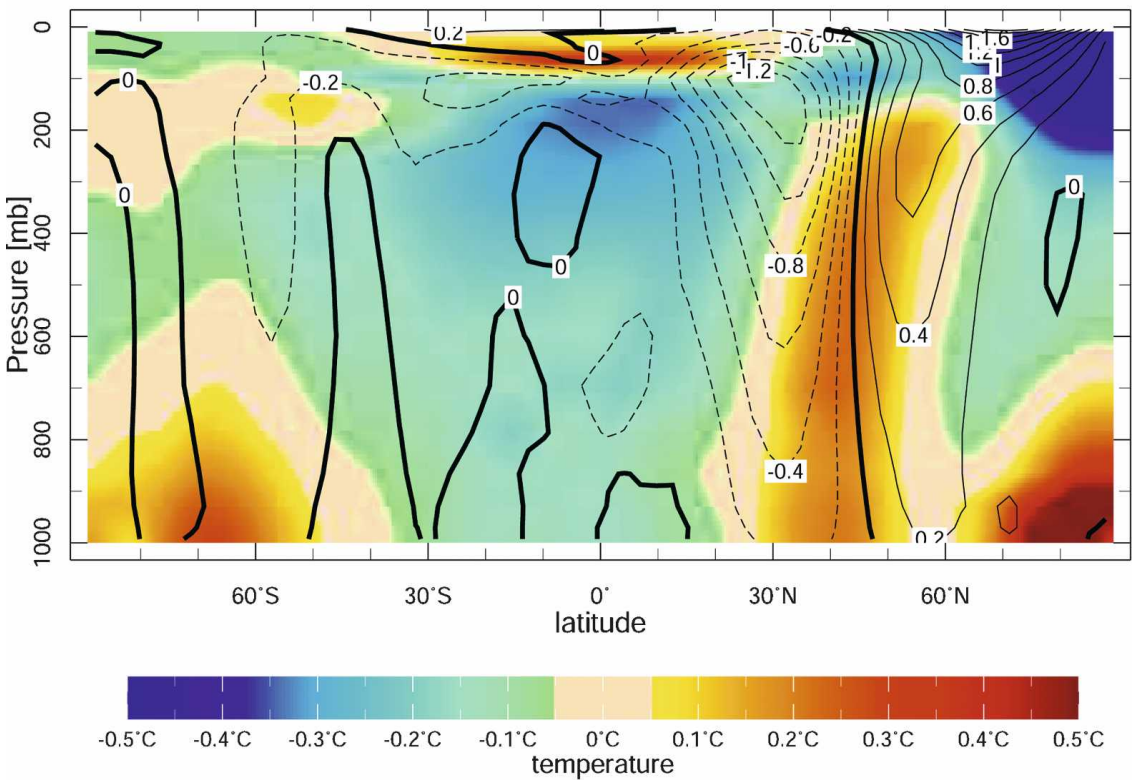

b) omega(colors), $u^{6} v^{6}$ (contours)
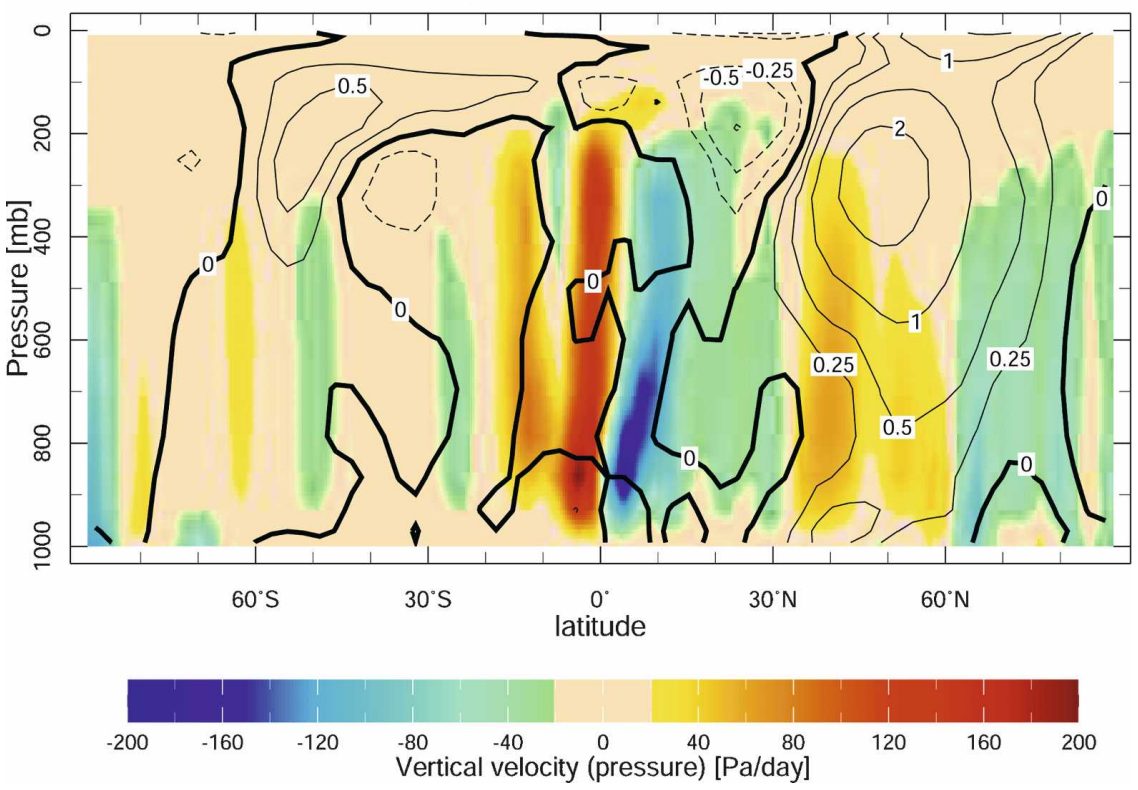

FIG. 7. The difference between (top) zonal mean temperature (colors) and zonal wind (contours) and (bottom) transient eddy momentum flux (colors) and subsidence (contours) between the A.D. 1360-1400 and modern (A.D. 1886-1998) periods. Units are in kelvin for temperature, $\mathrm{m} \mathrm{s}^{-1}$ for velocity, $\mathrm{m}^{2} \mathrm{~s}^{-2}$ for momentum flux, and $\mathrm{Pa} \mathrm{day}^{-1}$ for subsidence.

will cause transient eddies to propagate less far into the tropical upper troposphere. This should cause a dipole of anomalous transient eddy momentum flux $\left(\overline{\left(u^{\prime} v^{\prime}\right.}\right)$, with negative values in the subtropics and positive values farther poleward, which is seen in Fig. $7 b$ for the winter half-year of the strongest tropical-extratropical connection. In the zonal mean, indicated by angled brackets, the meridional eddy momentum flux convergence is balanced by the Coriolis torque operating on the mean meridional flow, namely, $-f\langle\bar{v}\rangle=-\left\langle\overline{u^{\prime} v^{\prime}}\right\rangle_{y}$. Consequently, the anomalous eddy momentum flux forces a mean poleward flow in the upper troposphere from the tropics into the midlatitudes; this forces descent in the midlatitudes (Fig. 7b), which 
a) Winter

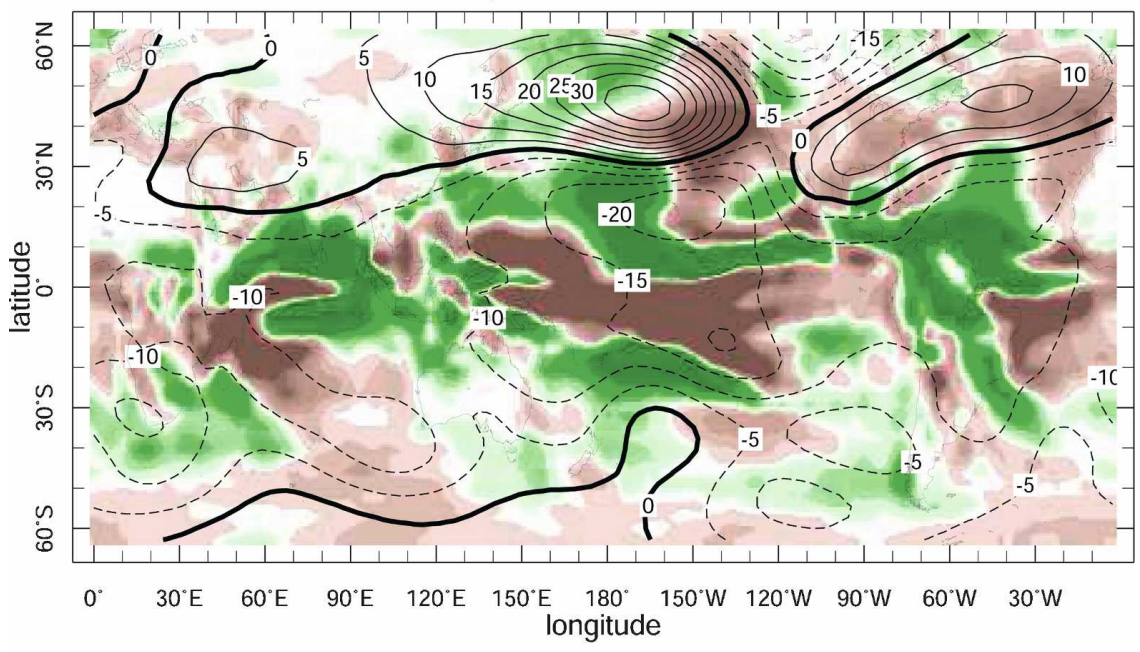

b) Summer
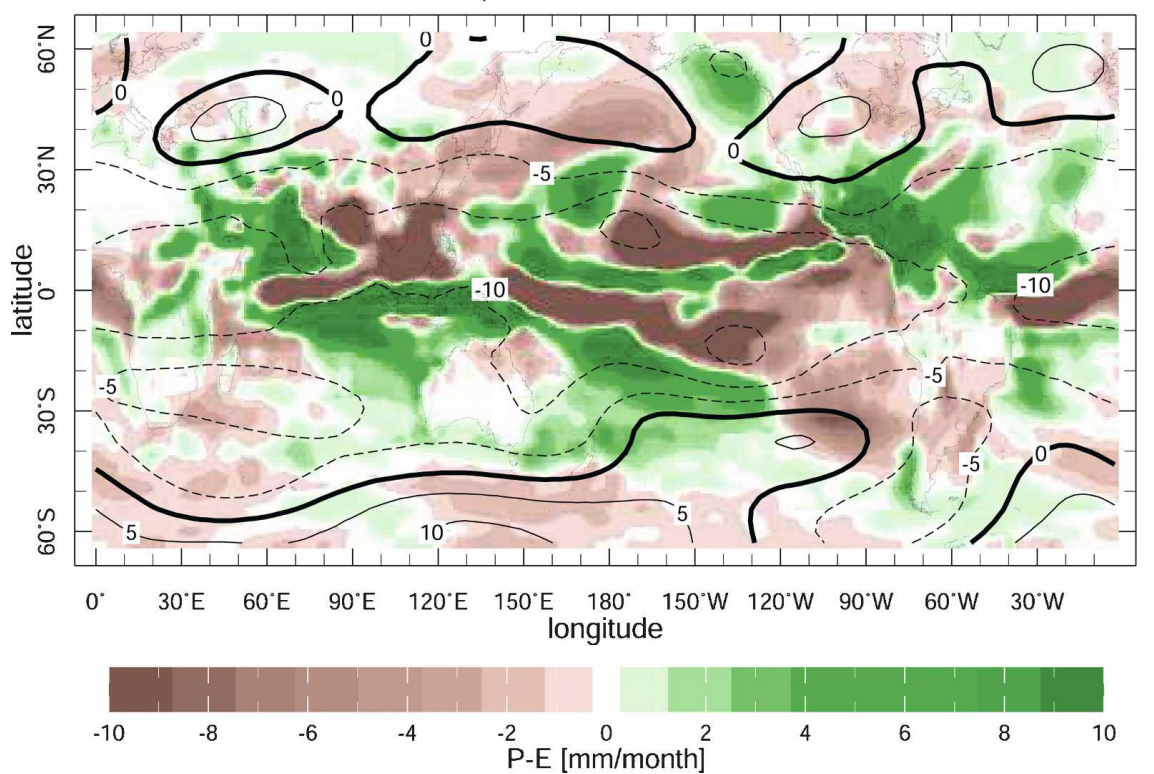

FIG. 8. The difference in $P-E$ (colors) and 200-mb geopotential height (contours) for the (top) winter and (bottom) summer half-year between the A.D. 1360-1400 and the modern (A.D. 1886-1998) periods. Units are $\mathrm{mm}$ month $^{-1}$ for $P-E$ and meters for geopotential height.

warms and suppresses precipitation. Seager (2007) provides a detailed quantitative demonstration of these links, and their impact on $P-E$, which we will not repeat here.

\section{Discussion and conclusions}

We have used a coral-based tropical Pacific SST field for the period of A.D. 1320-1462 to force an ensemble of atmosphere GCM simulations. The coral-based SSTs are overall colder than modern SSTs for most of this period (but by only a fraction of a degree Celsius), and the model accordingly makes western North America drier, akin to well-established relationships from the modern period, and confirmed from tree ring records of aridity. In addition, the model produces two longlasting periods of drought between A.D. $1360-1400$ and after A.D. 1430 that the tree ring records also identify as megadroughts. The atmospheric dynamics that link medieval tropical SSTs to drought over western North 
America are the same as those operating in modern droughts. However, despite the modest amplitude of the reconstructed SST changes, the modeled aridity averaged over the entire 143-yr period is in excess of that reconstructed from tree rings. This is partly due to the model's inability to produce the wetter interval that separated the late-fourteenth- and mid-fifteenthcentury megadroughts. Recent SST reconstructions (Black et al. 2007) suggest this was a cold period in the northern tropical Atlantic Ocean, which, if true, could have created a tendency to wetter conditions that offset Pacific-induced drying. That aside, the limited modelproxy reconstruction agreement makes clear that it would be wise to further pursue the role of Atlantic SST variations in forcing variations of medieval North American hydroclimate.

Despite these caveats, the degree of agreement between reconstructed hydroclimate and that modeled with tropical Pacific forcing alone is noteworthy in that 1) the tropical Pacific SSTs are reconstructed using coral records from a single place, 2) the dating of the coral records is uncertain to a few years, 3) coral geochemistry cannot be a perfect recorder of ocean temperature even locally, and 4) we ignore SST variations outside of the tropical Pacific that do not occur other than as a remote response to tropical Pacific variations. We also do not include any estimates of changes in solar irradiance or the impacts of volcanism, other than any possible indirect impact contained in the specified tropical Pacific SSTs. Because of these caveats the current results can only be taken as a demonstration that tropical Pacific SST variations were active in driving the megadroughts, but that there may have been other causes as well. For example, the modeled drought follows the tropical Pacific SSTs more closely than the observed record does. Random atmospheric variability can easily cause a deviation of the observed record from the SST-forced record for a year or so, but longerperiod deviations seem to suggest that either the coralbased SST reconstruction is in error or that SSTs in another basin, for example, the Atlantic, exerted an influence, as argued above.

This work suggests clear directions for future research. First, coral records appear to produce physically plausible magnitudes and temporal evolution of tropical Pacific SSTs, a conclusion based on the fact that when these SSTs are used to force an atmosphere model, the modeled hydroclimate in the West has some similarities to that reconstructed from tree ring records. Hence, efforts need to be made to increase the number of such proxy SST records to fill in the spatial and temporal gaps with the ultimate goal of providing reliable tropical SST fields with annual resolution for, say, the last millennium. This work will need to combine field and laboratory research with advanced statistical methods for dealing with sparse and irregularly spaced data (Evans et al. 2002). Second, this work indicates that it would be fruitful to use the same methods to model other periods covered by coral records of SSTs, that is, not just in the medieval period, but also during the subsequent Little Ice Age. The results presented here also motivate attempts at similar model experiments, with forcing from SSTs in other ocean basins reconstructed from high-resolution records.

While the current work suggests that the medieval $\mathrm{La}$ Niña-like state was an important driver of medieval aridity in North America, it leaves unanswered what caused the tropical Pacific to adopt that state. While a theory has been advanced that it was a response to anomalous positive solar radiative forcing (Mann et al. 2005; Seager et al. 2007b; Emile-Geay et al. 2007), this relies on calculations with an intermediate-complexity model of the tropical Pacific, with results that have not been confirmed with more complex models (Collins 2005; Vecchi et al. 2006; Vecchi and Soden 2007). Despite this modeling disagreement the relationship between positive radiative forcing and drought in the Southwest holds up throughout the Holocene in a speleothem record from New Mexico (Asmerom et al. 2007). Amid this confusing situation the reason why the tropical Pacific Ocean had the climate it did during the part of the medieval period analyzed here, and earlier (Cobb et al. 2003), remains an unanswered but critical question. Only when coupled climate models can explain the origins of medieval SST anomalies and their global impact can we be sure that they correctly represent the physical processes that link radiative forcing, tropical climate response, and global hydroclimate, and, hence, place full confidence in their projections of the hydroclimate response to anthropogenic forcing.

Acknowledgments. This work was supported by NOAA Grants NA030AR4320179 PO7 and 20A and NSF Grants ATM-0347009 and ATM-0501878. RB was supported by NOAA Grant NA17RJ1226. We thank Mark Cane for advice on the SST reconstruction, Wally Broecker for his skeptical assessment of the model results, and an anonymous reviewer for insightful criticisms. The model simulation data can be accessed online (http://kage.ldeo.columbia.edu:81/SOURCES/ .LDEO/.ClimateGroup/.PROJECTS/.CCM3).

\section{REFERENCES}

Alexander, M. A., I. Blade, M. Newman, J. R. Lanzante, N.-C. Lau, and J. D. Scott, 2002: The atmosphere bridge: The in- 
fluence of ENSO teleconnections on air-sea interaction over the global oceans. J. Climate, 15, 2205-2231.

Asmerom, Y., V. Polyak, S. Burns, and J. Rassmussen, 2007: Solar forcing of Holocene climate: New insights from a speleothem record, southwestern United States. Geology, 35, 1-4.

Black, D. E., M. A. Abahazi, R. C. Thunell, A. Kaplan, E. J. Tappa, and L. C. Peterson, 2007: An 8-century tropical Atlantic SST record from the Cariaco Basin: Baseline variability, twentieth-century warming, and Atlantic hurricane frequency. Paleoceanography, 22, PA4204, doi:10.1029/ 2007PA001427.

Bretherton, C. S., C. Smith, and J. M. Wallace, 1992: An intercomparison of methods for finding coupled patterns in climate data. J. Climate, 5, 541-560.

Clement, A. C., R. Seager, M. A. Cane, and S. E. Zebiak, 1996: An ocean dynamical thermostat. J. Climate, 9, 2190-2196.

Cobb, K., C. D. Charles, H. Cheng, and R. L. Edwards, 2003: El Niño/Southern Oscillation and tropical Pacific climate during the last millennium. Nature, 424, 271-276.

Collins, M., 2005: El Niño- or La Niña-like climate change? Climate Dyn., 24, 89-104.

Cook, E. R., and P. J. Krusic, 2004: North American summer PDSI reconstructions. IGBP PAGES/World Data Center for Paleoclimatology Data Contribution Series, 2004-045.

, C. Woodhouse, C. M. Eakin, D. M. Meko, and D. W. Stahle, 2004: Long term aridity changes in the western United States. Science, 306, 1015-1018.

_, R. Seager, M. A. Cane, and D. W. Stahle, 2007: North American droughts: Reconstructions, causes and consequences. Earth. Sci. Rev., 81, 93-134.

Crowley, T. J., 2000: Causes of climate change over the past 1000 years. Science, 289, 270-277.

Dillehay, T. D., 1974: Late Quaternary bison population changes in the southern plains. Plains Anthropol., 19, 180-196.

Douglass, A. E., 1929: The secrets of the Southwest solved by talkative tree rings. Natl. Geogr., 54, 737-770.

_ 1935: Dating Pueblo Bonito and other ruins of the southwest. National Geographic Society Technical Report, Pueblo Bonito Series 1, 74 pp.

Emile-Geay, J., M. A. Cane, R. Seager, A. Kaplan, and P. Almasi, 2007: El Niño as a mediator for the solar influence on climate. Paleoceanography, 22, PA3210, doi:10.1029/2006PA001304.

Evans, M. N., A. Kaplan, and M. A. Cane, 2002: Pacific sea surface temperature field reconstruction from coral $\delta^{18} O$ data using reduced space objective analysis. Paleoceanography, 17, 1007, doi:10.1029/2000PA000590.

Graham, N., and Coauthors, 2007: Tropical Pacific-mid-latitude teleconnections in medieval times. Climatic Change, 83, 241285.

Held, I. M., and B. J. Soden, 2006: Robust responses of the hydrological cycle to global warming. J. Climate, 19, 5686-5699.

Herweijer, C., R. Seager, and E. R. Cook, 2006: North American droughts of the mid to late Nineteenth Century: History, simulation and implications for Medieval drought. Holocene, 16, 159-171.

, — _ - , and J. Emile-Geay, 2007: North American droughts of the last millennium from a gridded network of tree ring data. J. Climate, 20, 1353-1376.
Hoerling, M. P., and A. Kumar, 2003: The perfect ocean for drought. Science, 299, 691-694.

Huang, H., R. Seager, and Y. Kushnir, 2005: The 1976/77 transition in precipitation over the Americas and the influence of tropical SST. Climate Dyn., 24, 721-740.

Kaplan, A., M. A. Cane, Y. Kushnir, A. C. Clement, M. B. Blumenthal, and B. Rajagopalan, 1998: Analyses of global sea surface temperature: 1856-1991. J. Geophys. Res., 103, 18 567-18 589.

Kiehl, J. T., J. J. Hack, G. B. Bonan, B. A. Bovile, D. L. Williamson, and P. J. Rasch, 1998: The National Center for Atmospheric Research Community Climate Model: CCM3. J. Climate, 11, 1131-1149.

Lu, J., G. Vecchi, and T. Reichler, 2007: Expansion of the Hadley Cell under global warming. Geophys. Res. Lett., 34, L06805, doi:10.1029/2006GL028443.

Mann, M., M. A. Cane, S. E. Zebiak, and A. Clement, 2005: Volcanic and solar forcing of the tropical Pacific over the past 1000 years. J. Climate, 18, 447-456.

Palmer, W. C., 1965: Meteorological drought. U.S. Weather Bureau Research Paper 45, 58 pp.

Rayner, N. A., D. E. Parker, E. B. Horton, C. K. Folland, L. V. Alexander, D. P. Rowell, E. C. Kent, and A. Kaplan, 2003: Global analyses of sea surface temperature, sea ice, and night marine air temperature since the late nineteenth century. $J$. Geophys. Res., 108, 4407, doi:10.1029/2002JD002670.

Schubert, S. D., M. J. Suarez, P. J. Region, R. D. Koster, and J. T. Bacmeister, 2004a: Causes of long-term drought in the U.S. Great Plains. J. Climate, 17, 485-503. Dust Bowl. Science, 303, 1855-1859.

Seager, R., 2007: The turn-of-the-century North American drought: Dynamics, global context, and prior analogs. J. Climate, 20, 5527-5552.

—, N. Harnik, Y. Kushnir, W. Robinson, and J. Miller, 2003: Mechanisms of hemispherically symmetric climate variability. J. Climate, 16, 2960-2978.

,-- W. A. Robinson, Y. Kushnir, M. Ting, H. P. Huang, and J. Velez, 2005a: Mechanisms of ENSO-forcing of hemispherically symmetric precipitation variability. Quart. J. Roy. Meteor. Soc., 131, 1501-1527.

- Y. Kushnir, C. Herweijer, N. Naik, and J. Velez, 2005b: Modeling of tropical forcing of persistent droughts and pluvials over western North America: 1856-2000. J. Climate, 18, 4068-4091.

—, N. Graham, C. Herweijer, A. Gordon, Y. Kushnir, and E. R. Cook, 2007a: Blueprints for Medieval hydroclimate. Quat. Sci. Rev., 26, 2322-2336.

- and Coauthors, 2007b: Model projections of an imminent transition to a more arid climate in southwestern North America. Science, 316, 1181-1184.

-, Y. Kushnir, M. Ting, M. A. Cane, N. Naik, and J. Velez, 2008: Would advance knowledge of 1930s SSTs have allowed prediction of the Dust Bowl drought? J. Climate, 21, 32613281.

Stahle, D. W., F. K. Fye, E. R. Cook, and R. D. Griffin, 2007: Tree ring reconstructed megadroughts over North America since AD 1300. Climatic Change, 83, 133-149.

Stine, S., 1994: Extreme and persistent drought in California and Patagonia during mediaeval time. Nature, 369, 546-549. 
van der Schrier, G., K. R. Briffa, T. J. Osborn, and E. R. Cook, 2006: Summer moisture availability across North America. $J$. Geophys. Res., 111, D11102, doi:10.1029/2005JD006745.

Vecchi, G. A., and B. J. Soden, 2007: Global warming and the weakening of the tropical circulation. J. Climate, 20, 43164340 .

A. T. Wittenberg, I. M. Held, A. Leetmaa, and M. J. Harrison, 2006: Weakening of tropical Pacific atmo- spheric circulation due to anthropogenic forcing. Nature, $\mathbf{4 4 1}$ 73-76.

Woodhouse, C. A., and J. T. Overpeck, 1998: 2000 years of drought variability in the central United States. Bull. Amer. Meteor. Soc., 79, 2693-2714.

Zhang, Y., J. M. Wallace, and D. S. Battisti, 1997: ENSO-like decade-to-century scale variability: 1900-93. J. Climate, 10, 1004-1020. 